УДК $662.995: 662.997$

DOI https://doi.org/10.15673/swonaft.v84i1.1877

\title{
PERFORMANCE OF ADSORPTIVE HEAT-MOISTURE REGENERATOR
}

\author{
Belyanovskaya E.A. ${ }^{1}$, PhD, docent, \\ Lytovchenko R.D. ${ }^{1}$, postgraduate student, \\ Sukhyy K.M. ${ }^{1}$ SciD, Prof., \\ Sukhyy M.P. ${ }^{1}$ PhD, Prof., \\ Gubynskyi M.V. ${ }^{2}$, SciD, Prof. \\ Sukha I.V. ${ }^{1}$, PhD, docent, \\ ${ }^{1}$ State Higher Education Institution «Ukrainian State University of Chemical Engineering», \\ Dnipro, Ukraine \\ ${ }^{2}$ National metallurgical academy of Ukraine, \\ Dnipro, Ukraine
}

\begin{abstract}
The performance of the adsorptive heat-moisture regenerators based on the composite materials 'silica gel - sodium acetate' and 'silica gel - sodium sulphate' have been studied. The mathematical model and algorithm for determining the basic operating parameters of adsorptive regenerator in the housing and communal services sector have been further developed. The proposed algorithm which involves calculating the air volume passed through the adsorbent layer, the final absolute humidity of air near the outlet from the regenerator, the adsorption and the heat of adsorption during inflow and outflow, the final temperature of the external cold air, the air temperature after mixing the cold external air and the internal warm air in the room near the warm end of the regenerator during inflow, the air temperature after mixing of the cold external air and the warm exhaust air from the premise near the cold end of regenerator during outflow, determining the temperature and moisture efficiency factors has been completed by computing the Reynolds criterion of the adsorbent layer, the coefficient of the hydraulic resistance, the pressure loss, the consumed power of ventilator, summarized adsorption and time to achieve maximal adsorption. The adequacy of suggested mathematical model is confirmed by sufficient correlation of experimental data and calculation results with the proposed algorithm. The performance of adsorptive regenerators based on the adsorbents 'silica gel $-\mathrm{CH}_{3} \mathrm{COONa}$ ' and 'silica gel - $\mathrm{Na}_{2} \mathrm{SO}_{4}$ ' has been simulated in the conditions of the conventional ventilation system of living quarters. The efficiency of adsorptive regenerators has been compared when 'silica gel $-\mathrm{CH}_{3} \mathrm{COONa}$ ' and 'silica gel $-\mathrm{Na}_{2} \mathrm{SO}_{4}$ ' used. The correlation of design and efficiency of adsorptive regenerators is shown.
\end{abstract}

Key words: adsorptive heat-moisture regenerator, heat regeneration factor, moisture regeneration factor, composite adsorbent, ventilation.

\section{ЕКСПЛУАТАЦІЯ АДСОРБЦЙНОГО РЕГЕНЕРАТОРА ТЕПЛОТИ ТА ВОЛОГИ}

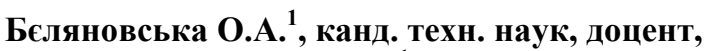 \\ Литовченко Р.Д. ${ }^{1}$, аспірант, \\ Сухий К.М. ${ }^{1}$, д-р техн. наук, професор, \\ Сухий М.П.' канд. техн. наук, професор \\ Губинський М. В. ${ }^{2}$, д-р техн. наук, професор, \\ Суха I.B. ${ }^{1}$, канд. техн. наук, доцент \\ ${ }^{1}$ ДВНЗ «Український державний хіміко-технологічний університет», \\ м. Дніпро \\ ${ }^{2}$ Національна металургійна академія України, \\ м. Дніпро
}

\begin{abstract}
Анотація. Досліджені процеси експлуатації адсорбційних регенераторів теплоти та вологи на основі композитів «силікагель - натрій ацетат» та «силікагель - натрій сульфат». Отримали подальшій розвиток математична модель та алгоритм визначення основних екплуатаційних параметрів адсорбиійних
\end{abstract}




\section{Одеська національна академія харчових технологій ІННОВАЦИЙН ОБЛАДНАННЯ ХАРЧОВИХ,

регенераторів в умовах систем вентиляиії сектора житлово-комунального господарства. Запропонований алгоритм, який включає обчислення об'єму повітря, щзо проходить через шар адсорбенту, кінцевої абсолютної вологості повітря біля виходу з регенератора, адсорбиії та теплоти адсорбиії під час припливу та викиду, кінцевої температури холодного повітря, температур повітря біля теплого кіния регенератора після змішування холодного зовнішнього повітря з вулиці та теплого внутрішнього повітря в приміщенні під час припливу та біля зовнішнього холодного кінця регенератора після змішування холодного зовнішнього повітря та теплого повітря з приміщення під час викиду, визначення коефіцієнтів регенерації теплоти та вологи, доповнено розрахунком критерію Рейнольдса шару адсорбенту, коефіцієнта гідравлічного опору, втрати тиску, споживаної потужності вентилятора, сумарної адсорбиії та часу досягнення максимальної адсорбиії. Адекватність запропонованої математичної моделі підтверджується результатами розрахунків за запропонованим алгоритмом та експериментальними даними. Проведено симуляцію процесів експлуатації регенераторів на основі композитів «силікагель - $\mathrm{CH}_{3} \mathrm{COONa»} \mathrm{та} \mathrm{силікагель} \mathrm{-} \mathrm{Na}_{2} \mathrm{SO}_{4}$ » 6 умовах типової вентиляційної системи житлових приміщень. Порівняно ефективність адсорбиійних

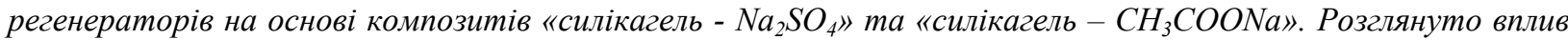
конструкиії адсорбиійних регенераторів на їх ефективність.

Ключеві слова: адсорбційний регенератор теплоти та вологи, коефіцієнт регенерації теплоти, коефіцієнт регенерації вологи, композитний адсорбент, вентиляція.

A major source of global and energy consumption is building. Heat, ventilation and conditioning (HVAC) systems strongly determine the thermal comfort and indoor air quality. Most conventional method of sustaining a thermal comfort of indoor air quality is air cooling or heating in surface heat exchangers. As a rule such systems are based on vapor compression chilling machines which results in significant electric load. So, systems of HVAC are responsible for a substantial proportion of energy consumption in modern buildings [1].

Moreover, adsorptive processes are suggested for storage, conversion and regeneration low-potential heat. Silica gels, zeolites and silicaaluminophosphate were shown to be promising for an adsorptive dehumidification of air $[2,3]$. Adsorptive heat storage and conversion devices were developed and tested in the Germany [4], Netherlands [5], Slovenia [6] and Great Britain [7]. Most of such systems are based on conventional adsorbents. However, their poor adsorptive properties necessitate high volumes of adsorbent to supply required heat load. This problem is solved by developing systems with multiple adsorptive units [6] or with divided reactors for adsorption, regeneration and storage of an adsorbent [8]. Both ways lead to complication of design and performance of heat conversion system. In the light of adsorptive capacity, i.e. water uptake, advanced materials for inflow air heating and conditioning are composite sorbents of the type 'salt in the porous matrix' [9]. Systems, devices and units based on them can sustain a comfort temperature and humidity of indoor premise [10].

Nevertheless, a large-scale implementation of devices along with the low adsorptive properties of convenient adsorbents and deficiency of simple operating procedure of obtaining adsorbents 'salt inside porous matrix' is restricted by the lack of an algorithm for their calculation, which allows to simulate and study the processes of their operation in the conditions of real ventilation systems. Despite the fact that adsorptive heat storage and conversion systems and devices work in two-phase mode, such studies are focused on only one stage of operation, i.e. adsorption $[11,12]$. Mathematic model of performance of adsorptive heat-moisture regenerator suggested in [13, 14] allows evaluating only temperature efficiency factor. Nevertheless, the energy performance of the heat-moisture regenerators is characterized not only by temperature efficiency factor, but humidity efficiency factor. Moreover, it is advisable to estimate consumed power of service equipment.

The aim of present work is estimate the performance characteristic of heat-moisture regenerator for ventilation system. To accomplish this purpose, the following tasks are set:

- to reveal basic design characteristics of adsorptive heat-moisture regeneration unit based on composite adsorbents under conditions of ventilation system of housing and utilities sector;

- to determine correlation between design and operation parameters and energy efficiency of adsorptive heat conversion unit;

- to estimate the characteristics of service equipment.

Experimental. The design of the adsorptive regeneration unit is presented in [13, 14]. Length of laboratory prototype of heat regenerator is $0.6 \mathrm{~m}$ [15]. Composites 'silica gel - sodium acetate' or 'silica gel - sodium sulphate' were used. They were synthesized by sol - gel method according to technique described in [16].

The device is operated in two-phase mode which involves alternating modes 'inflow' and 'outflow' [13, 14]. When inflowed, ambient air is intaken by inner ventilator and got through the adsorbent layer into premise, air flow being heated and water excess being adsorbed. When outflowed, inner ventilator is stopped and air is intaken by external ventilator and released into outdoor environment. So, premise ventilation occurs, while temperature and humidity of indoor premise remain stable. The outer and inner ends of studied device are considered to be cold and warm, respectively. 
According to the given phases, an algorithm for calculating the performance of adsorptive heat and moisture regenerator has been developed (Fig. 1).

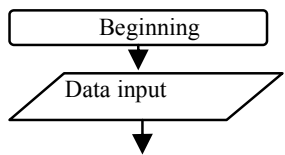

1. Calculation final absolute humidity of the inflow air

2. Computing the inflowed air volume which supplied to layer of adsorbent.

3. Computing the adsorption when inflowed.

4. Calculating the adsorption during inflow.

5. Calculating of final temperature of external cold air when inflowed.

6. Computing the air temperature near the inner end of regenerator after mixing the

cold external air and warm internal air in the premise during inflow.

7. Calculating the final absolute humidity of outflowed air.

8. Computing the volume of the exhaust air passed through an adsorbent layer.

9. Calculation of adsorption during outflow.

10. Calculating adsorption heat when outflowed.

1. Computing the final temperature of outflowed air

12. Calculation of the air temperature near the external cold end of the regenerato fter mixing the cold external air and warm exhaust air.

13. Computing the heat regeneration factor.

4. Calculating of the moisture regeneration factor.

5. Determination of the equivalent diameter of the channel

6. Calculation of the Reynolds criterion of the adsorbent layer.

7. Calculation of the coefficient of the hydraulic resistance.

8. Calculation of the pressure loss.

19. Calculation of consumed power of ventilator.

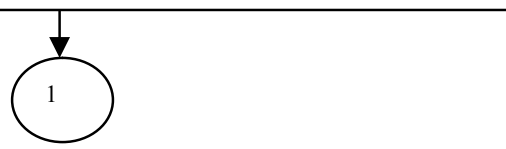

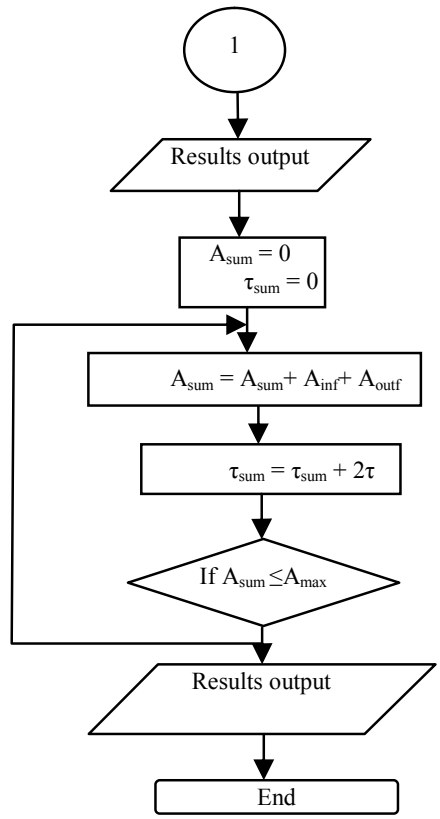

Fig. 1 - Algorithm of calculating the operating parameters of adsorptive regenerator [15]

The heat regeneration factor i.e. temperature efficiency factor is determined by the formula $[13,14]$ :

$$
\eta_{\text {tem }}=\frac{t_{\text {inf }}-t_{\text {ext }}}{t_{\text {out }}-t_{\text {ext }}}
$$

where $t_{\text {inf }}$ referred to temperature of inflowing air, ${ }^{\circ} \mathrm{C}$; $t_{\text {ext. }}$ corresponds with temperature of external air; $t_{\text {out }}$ is temperature of outgoing air.

According to algorithm described in [14], temperatures of inflowing and outflowing air are determined as a temperatures after mixing the cold supplied air and the warm internal air during inflow and cold external air and warm exhausted air from the room. Final temparatures of inflowed and outflowed air are described by thermal balance equations. The air volume which passed through the adsorbent layer during air-in or air-out modes, mass transfer coefficient, final values of absolute humidities, adsorption, heat of adsorption at the inflow or outflow are determined according to [13]. Then, summarized adsorption and time of saturation of adsorbent layer, ie time required to achieve maximal adsorption are calculated according to control-flow chart (Fig. 1).

The moisture regeneration factor or moisture efficiency factor is calculated as [15]:

$$
\eta_{\text {hum }}=\frac{\mathrm{C}_{\text {ext }}-\mathrm{C}_{\text {inf }}}{\mathrm{C}_{\text {ext }}-\mathrm{C}_{\text {out }}}
$$

$\eta_{\text {hum }}$ corresponds with the moisture efficiency factor or moisture regeneration coefficient; $\mathrm{C}_{\text {inf }}$, is the absolute humidity of the inflowing air, $\mathrm{kg} / \mathrm{m}^{3} ; \mathrm{C}_{\text {ext }}$, is the absolute humidity of the external air, $\mathrm{kg} / \mathrm{m}^{3} ; \mathrm{C}_{\text {out }}$, is the absolute humidity of outgoing air, $\mathrm{kg} / \mathrm{m}^{3}$.

The absolute humidity of the inflowing air is proposed to be calculated as the final absolute humidity of air during inflow. The absolute humidity of exhaust air is suggested to be calculated as the absolute humidity after mixing the cold outdoor air and warm outflowing air [15]:

$$
\mathrm{C}_{\text {fin.str.aft.mix. }}=\frac{\mathrm{V}_{\text {str }} \cdot \mathrm{C}_{0 . \mathrm{str}}+\mathrm{V}_{\text {outf }} \cdot \mathrm{C}_{\text {fin.str }}}{\mathrm{V}_{\text {str }}+\mathrm{V}_{\text {outf }}}
$$

where $\mathrm{V}_{\text {str }}$, is volume of air near the outside end of the regenerator, $\mathrm{m}^{3} ; \mathrm{C}_{0}$-str, refers to the initial absolute humidity of the outdoor air when ejected from the room, $\mathrm{kg} / \mathrm{m}^{3} ; \mathrm{C}_{\text {fin } \cdot \text { str }}$, is the final absolute humidity of warm air when outflowed, $\mathrm{kg} / \mathrm{m}^{3}$.

Hydrodynamic resistance of adsorbent layer is calculated as follows [15, 17]

$$
\xi=\frac{\mathrm{B}}{\mathrm{Re}_{1}}
$$




\section{Одеська національна академія харчових технологій \\ ІННОВАЦІЙНЕ ОБЛАДНАННЯ ХАРЧОВИХ, \\ ФАРМАЦЕВТИЧНИХ, ХІМІЧНИХ ТА ПАРФУМЕРНИХ ВИРОБНИЦТВ}

where $\mathrm{B}$ refers to the empiric factor which is taken as 1900 [17], $\mathrm{Re}_{1}$ corresponds with Reynolds criteria for air flow passed through the adsorbent layer. Considering preliminary calculations, values of $\operatorname{Re}_{1}$ correspond with laminar flow regime, they are at most of $30-40$.

Pressure loss is determined by the equation of Darsy - Weisbach as follows $[15,17]$ :

$$
\Delta \mathrm{p}=\xi \cdot \frac{w^{2}}{2} \cdot \rho \cdot \frac{\mathrm{H}}{\mathrm{d}_{\text {e.ch }}}
$$

where $\Delta \mathrm{p}$ refers to pressure loss, $\mathrm{Pa}$; w corresponds with the velocity of humid air, $\mathrm{m} / \mathrm{s} ; \xi$ is hydrodynamic resistance of adsorbent layer; $\rho$ is the air density, $\mathrm{kg} / \mathrm{m}^{3} ; \mathrm{H}$ corresponds with the thickness of the adsorbents layer, $\mathrm{m} ; \mathrm{d}_{\mathrm{e} . \mathrm{ch}}$ refers to the equivalent diameter of channel, $\mathrm{m}$.

The equivalent diameter of channel is computed as follows $[15,117]$ :

$$
\mathrm{d}_{\mathrm{e} . \mathrm{ch}}=\frac{2}{3} \cdot \frac{\varepsilon}{1-\varepsilon} \cdot \mathrm{d}
$$

where $d_{e . c h}$ is the equivalent diameter of channel, $\mathrm{m}, \varepsilon$ refers to the fractional void volume which is taken as 0.259 according with the most tight stowage of spheres [16], d corresponds with the diameter of adsorbent granule, $\mathrm{m}$.

Consumed power of ventilator is calculated as follows $[15,18]$ :

$$
N=\frac{v \cdot \Delta p}{\eta_{v e n t}}
$$

where $\mathrm{N}$ refers to the consumed power of ventilator, $\mathrm{W} ; \mathrm{v}$ corresponds with airflow, $\mathrm{m}^{3} / \mathrm{s} ; \Delta \mathrm{p}$ is the pressure loss, $\mathrm{Pa} ; \eta_{\text {vent }}$ refers to the efficiency factor of ventilator used.

Results and discussion. Proposed algorithm of calculation has been validated by experimental data presented in [18]. The results of the calculations exhibit the periodical changing the temperatures and absolute humidities near the external and internal ends of the adsorptive regenerator, which qualitatively correspond with the experimental data (Fig. 2).

The difference of the calculated temperatures and the experimental data does not surpass $2-3^{\circ} \mathrm{C}$ near the cold end of the regenerator, and $1-5^{\circ} \mathrm{C}$ near the warm one. When composite 'silica gel - sodium sulphate used', the temperature efficiency factor of the regenerator according to the experimental data is approximately $95 \%$, and

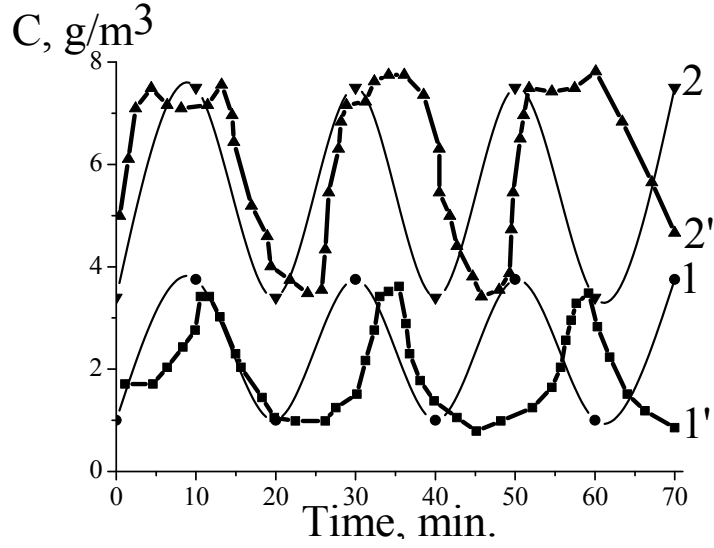

1,2-results of calculation; 1', 2'-experimental results; 1, 1'-absolute humidities on internal end of regenerator; 2, 2' - absolute humidities on external end of regenerator

Fig. 2 - Periodic dependences of absolute humidity of adsorptive heat-moisture regenerator based on composite 'silica gel - sodium acetate' according to the calculated it being about of $91 \%$ [14]. At that, calculated and experimental moisture efficiency factor are 59 and $64 \%$, respectively [15]. Experimental values of heat and moisture regeneration coefficients of regenerator based on composite 'silica gel - sodium acetate' are 85 and $62 \%$, respectively, while calculated values are $82 \%$ and $58 \%$. So, proposed mathematical model is acceptable for for qualitative evaluation of the performance characteristics of adsorptive heat-moisture regenerators in ventilation systems.

An adsorption regenerator is suggested to use when the inflow air heated in the conditions of a convenient three-room apartment with electric cookers, a total area and a height are of $103 \mathrm{~m}^{2}$ and 2.5 meters, respectively. According to the results of the calculation by the Sanitary Regulations 2.04.0591, the thermal load for heating the supply air is about 338.26 MJ per a day which corresponds with 6 hours of work per a day.

As an adsorptive material, the composites containing 20\% silica gel and $80 \%$ sodium sulphate or sodium acetate are proposed to use $[13,14]$. The mass of the adsorbents 'silica gel - sodium acetate' and 'silica gel - sodium sulphate' required to supply the thermal load are evaluated as 182 and $96.5 \mathrm{~kg}$. For the handling capability of the regenerator, it is an optimal option to install in the ventilation scheme of 3bedroom apartments four adsorptive regenerators. So, the mass of the composite 'silica gel - sodium acetate' and 'silica gel - sodium sulphate' are 46 and $25 \mathrm{~kg}$ per one regenerator. The results of the calculations are given in Fig. 3 and 4. The temperatures and absolute humidities of air near the internal and external ends of the regenerators are stated to be periodically varied. The amplitude of the temperature dependencies and time of switching of the airflow are decreased simultaneously. This leads to the increasing the temperature efficiency factors. Maximal values of 
temperature efficiency factors are achieved at time of switching the flows at most of 5 min and airflow speeds not above of $0.22 \mathrm{~m} / \mathrm{s}[14,19]$.

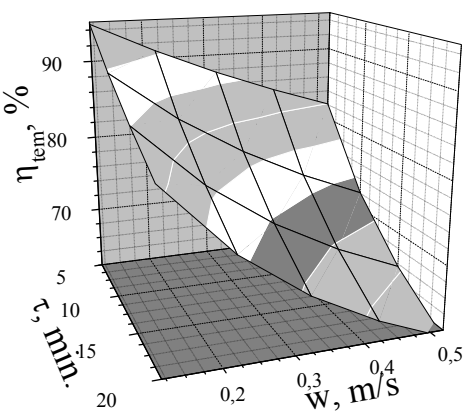

a

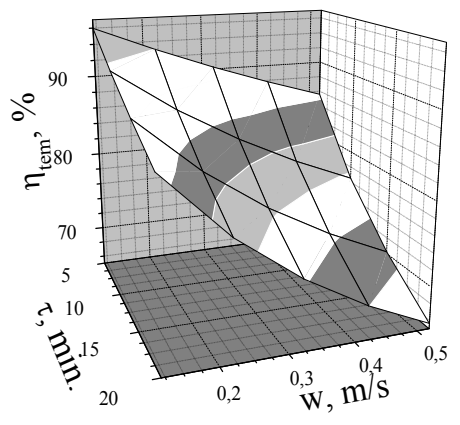

b

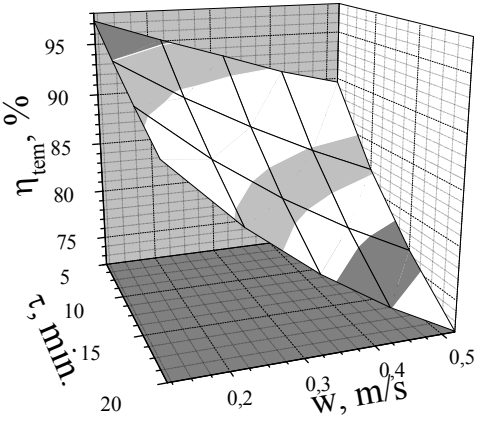

c

$a-0.0628$ and $0.53 ; b-0.03925$ and $0.848 ; c-0.0314$ and 1.06. Absolute humidity of outdoor air is $6.5 \mathrm{~g} / \mathrm{m}^{3}$, absolute humidity of the indoor air is $1.0 \mathrm{~g} / \mathrm{m}^{3}$

Fig. 3 - Heat regeneration factor vs. airflow speed and time of switching airflows for adsorptive regenerators of heat and moisture based on composite ' $20 \%$ silica gel- $80 \% \mathrm{Na}_{2} \mathrm{SO}_{4}$ '. Area of cross-section of adsorbent layer, $\mathrm{m}^{2}$ and thickness of the adsorbent layer, $\mathrm{m}$

The heat regeneration factors of device based on composites 'silica gel - sodium sulphate' are observed to surpass these values for regenerators with 'silica gel $-\mathrm{CH}_{3} \mathrm{COONa}$ ' in the very least by $9-10 \%$. However, absolute humidity of inflowing air remains almost constant. So, moisture efficiency factors are not changed. They are esti-

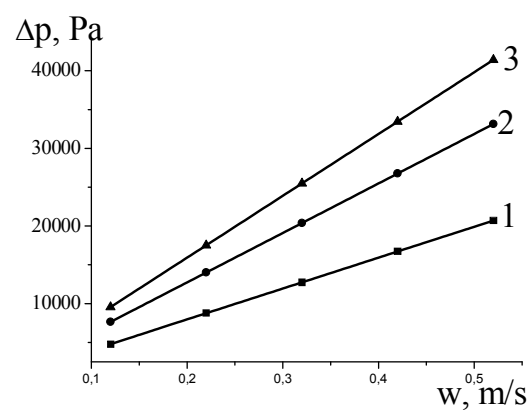

a

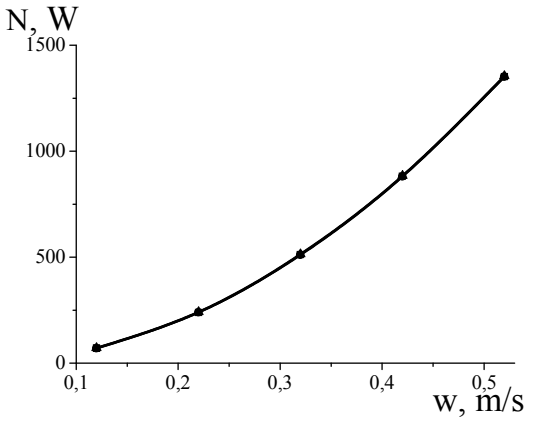

b

$1-0.0628$ and $0.53 ; 2-0.03925$ and $0.848 ; 3-0.0314$ and 1.06

Fig. 4 - Pressure loss (a) and consumed power (b) of adsorptive regenerator of heat and moisture based on silica gel - $\mathrm{Na}_{2} \mathrm{SO}_{4}$ ' vs. air flow speed. Area of cross-section of adsorbent layer, $\mathrm{m}^{2}$ and thickness of the adsorbent layer, $\mathbf{m}$

mated as $58 \%$ and $59 \%$ when 'silica gel $-\mathrm{CH}_{3} \mathrm{COONa}$ ' and 'silica gel $-\mathrm{Na}_{2} \mathrm{SO}_{4}$ ' used.

Performance of adsorptive heatmoisture regenerator is strongly determined by its design characteristics (Fig. 3). Decreasing of crosssection area of adsorbent layer leads to increasing the temperature efficiency factor. Pressure loss is strongly affected by air flow speed and thickness of adsorbent layer (Fig. 4). Values of $\Delta p$ are increased proportionally $\mathrm{w}$ and $\mathrm{H}$, according to Eq. (5) and (7).

Consumed power of ventilator is increased proportionally with $\mathrm{w}^{2}$. Minimal values of consumed power

of ventilator are of $70-250 \mathrm{~W}$ are revealed at $0.12-0.22 \mathrm{~m} / \mathrm{s}$ which correspond with maximal values of heat regeneration factor. Consumed power of standard conditioners working for air heating in the premises of $15-140 \mathrm{~m}^{2}$ is ranged from 0.6 up to $2.9 \mathrm{~kW}$ [20]. It should be noted that as compared with adsorptive regenerator in the heating mode such conditioners can sustain only relative humidity of the internal air.

Conclusions. The performance of adsorptive regenerator of heat and moisture has been studied. The method of determination of the main performance characteristics of the adsorptive regenerator under the conditions of the ventilation system in the residential premises has been further developed. The dependence of the value of the heat regeneration factor vs. airflow speed and the time of switching flows is shown. Optimal values of time of switching the flows and airflow speed which corresponded with maximal values of heat regeneration factor is stated to be at most of $5 \mathrm{~min}$ and $0.12-0.22 \mathrm{~m} / \mathrm{s}$. At these conditions are stated minimal values of pressure drop and consumed power of ventilator.

Design of adsorptive heat moisture is shown to affect the efficiency of the regenerator. Procedure of estimation of design and performance of adsorptive regenerators has been proposed. Increasing of temperature efficiency factor when cross-section are of adsorbent layer decreased is shown. Maximal values of heat regeneration factor are determined at area of cross-section of adsorbent layer of $0.0314-0.03925 \mathrm{~m}^{2}$. 


\section{Одеська національна академія харчових технологій ІННОВАЦІЙНЕ ОБЛАДНАННЯ ХАРЧОВИХ, ФАРМАЦЕВТИЧНИХ, ХІМІЧНИХ ТА ПАРФУМЕРНИХ ВИРОБНИЦТВ}

This work was supported within the framework taxpayer-funded research 0119U002243 of Ministry of Education and Science of Ukraine.

\section{References}

1. Che, W.W., Tso, C. Y., Sun, L., Ip D.Y.K. , Lee, H. , Chao, C.Y.H., Lau, A. K.H. (2019). Energy consumption, indoor thermal comfort and air quality in a commercial office with retrofitted heat, ventilation and air conditioning (HVAC) system. Energy \& Buildings, 201, $202-215$

2. Erdogan, M., Bau, U., Bardow, A. (2019). Benchmarking commercial adsorbents for drying air in a packed bed. Applied Thermal Engineering, 160, 113942

3. Manyumbua, E., Martin, V., Fransson, T. (2014). Simple mathematical modeling and simulation to estimate solar-regeneration of a silica gel bed in a naturally ventilated vertical channel for Harare, Zimbabwe. Energy Procedia, 57, 1733 - 1742

4. Scapino, L., Zondag, H. A., Van Bael, J., Diriken, J., Rindt, C. C. M. (2017). Sorption heat storage for longterm low-temperature applications: A review on the advancements at material and prototype scale. Applied Energy, 190, 920-948.

5. Jong, A.-J., Trausela, F., Fincka, C., van Vlieta, L., Cuypers, R. (2014). Thermochemical heat storage - system design issues. Energy Procedia, 48, 309-319.

6. Stritih, U., Bombač, A. (2014). Description and Analysis of Adsorption Heat Storage Device, Strojniški vestnik. Journal of Mechanical Engineering, 60, 619-628.

7. Wajid,N., Mempouo, B., Dodo, A., Omer, S., Riffat, S. B. (2016). Experimental study of an adsorption heat storage systems for building applications. Renewable Bioresources, 4(2), $1-7$

8. Mette, B., Kerskes, H., Drück, H., Müller-Steinhagen, H. (2013). New highly efficient regeneration process for thermochemical energy storage. Applied Energy, 109, 352 - 359

9. Gordeeva, L.G., Aristov, Yu.I. (2018). Adsorptive heat storage and amplification: new cycles and adsorbents, Energy, 167, $440-453$.

10. Girnik, I., Yang, T., Gordeeva, L., Wang, W., Ge, T., Aristov, Yu. (2020). New Adsorption Method for Moisture and Heat Exchange in Ventilation Systems in Cold Countries: Concept and Mathematical Simulation. Energies, 13, $1386-1399$.

11. Gaeini, M., Zondag, H.A.,. Rindt, C.C.M. (2016). Effect of kinetics on the thermal performance of a sorption heat storage reactor, Appl. Therm. Eng., 102, 520- 531 .

12. Michel, B., Neveu, P., Mazet, N. (2014). Comparison of closed and open thermochemical processes, for longterm thermal energy storage applications. Energy, 72, $702-716$.

13. Belyanovskaya, E.A., Lytovchenko, R.D., Sukhyy, K.M.,Yeremin, O. O., Sukha, I. V., Prokopenko, E.M. (2019). Operating regime of adsorptive heat-moisture regenerators based on composites «silica gel - sodium sulphate' and 'silica gel - sodium acetate'. J. Chem. and Chem. Technology. 27, 158-168.

14. Belyanovskaya, E.A., Lytovchenko, R.D., Sukhyy, K.M., Prokopenko, O.M., Yeromin, O.O., Sukha, I.V. (2019). Choice criteria of adsorbents for heat energy converters in ventilation systems. Scientific works ONAFT, 83(1), $3-9$.

15. Belyanovskaya, E.A., Rimár, M., Lytovchenko, R.D., Variny, M.V., Sukhyy, K.M., Yeromin, O.O.,. Sykhhyy, M. P, Prokopenko, E. M., , Sukha, I.V., Gubinskyi, M. V., Kizek, J. (2020). Performance of Adsorptive HeatMoisture Regenerator Based on Composites 'Silica Gel - Sodium Sulphate'. Sustainability, 12, 5611

16. Sukhyy, K.M., Belyanovskaya, E.A., Kozlov, Ya.N., Kolomiyets, E.V., Sukhyy, M.P. (2014). Structure and Adsorption Properties of the Composites 'Silica Gel - Sodium Sulphate', obtained by Sol - Gel Method. Applied Thermal Eng., 64, $408-412$.

17. Bratchikov, S.G. (Ed.). (1970). Heat engineering of lumping of iron ore raw materials. M.: Metallurgia.

18. Kolomiyets, O. V., Sukhyy, K. M., Belyanovskaya, E. A., Tomilo, V. I., Prokopenko, O. M. (2016). Operating characteristics of adsorptive regenerator of low-potential heat and moisture based on composite sorbents 'silica gel - sodium sulphate and silica gel - sodium acetate' synthesized by sol - gel method. Scientific works ONAFT, 80(1), $108-113$.

19. Belyanovskaya, E.A., Lytovchenko, R.D., Sukhyy, K.M., Sukhyy, M.P., Gubynskyi, M.V. Sukha, I.V. (2020). Ekspluataciya regeneratora teploty` ta vology` na osnovi kompozy`tny`x adsorbentiv «sy`likagel - natrij sulfat», Trudy' XVIII Mizhdnarodna nauchno-praktychna konferenciya "Vdokonalennya processiv ta obladnannya kharchovykh i khimichnykh vyrobnitsv". Odessa: ONAFT, 57.

20. Ananyev, V.A., Baluyeva, L.N. et al. (2001). Systems of ventilation and conditioning. Theory and practice. Moskaw: Evroklimat.

Отримано в редакцію 29.07.2020

Прийнято до друку 04.11.2020
Received 29.07.2020

Approved 04.11.2020 